\title{
Zanesenost u akademskim aktivnostima i dobrobit studenata
}

\author{
Majda Rijavec i Tajana Ljubin Golub \\ Sveučilište u Zagrebu, Učiteljski fakultet u Zagrebu, Hrvatska
}

\begin{abstract}
Sažetak
Zanesenost je izrazito ugodno psihološko stanje koje ljudi doživljavaju kada su u tolikoj mjeri usmjereni na aktivnost kojom se trenutno bave da su potpuno njome zaokupljeni. Glavni je uvjet za pojavu stanja zanesenosti ravnoteža između izazova i vještina, pri čemu i izazovi i vještine moraju za pojedinca biti iznadprosječni. Zanesenost se najčešće istraživala u slobodnim aktivnostima, ali je ljudi doživljavaju i u aktivnostima koje su nametnute ili u njima ima manje slobode izbora, kao što su posao i obrazovanje. Zanesenost ima pozitivne posljedice ne samo na učinkovitost u različitim područjima života nego i na dobrobit pojedinca. I u akademskom je kontekstu zanesenost povezana s različitim pozitivnim ishodima, uključujući bolje svladavanje nastavnog programa, veća akademska postignuća, ali i veću dobrobit studenata. Kada je u pitanju studentska populacija, iskustva zanesenosti u akademskim aktivnostima manje su učestala nego u ostalim područjima studentskog života (slobodno vrijeme, uobičajene svakodnevne aktivnosti, povremeni posao), ali je veza između zanesenosti i dobrobiti najizraženija upravo u akademskom kontekstu. U ovom se radu daje pregled istraživanja akademske zanesenosti u studentskoj populaciji, posebno onih koja upućuju na moguće uzroke navedene povezanosti, kao što su važnost i korisnost akademskih aktivnosti za ostvarenje budućih životnih ciljeva, važnost akademskih aktivnosti za izgradnju socijalnog identiteta te smanjenje akademskog stresa i sagorijevanja.
\end{abstract}

Ključne riječi: akademska zanesenost, dobrobit, socijalni identitet, akademski stres, studenti

\section{Uvod}

Pojavom se pozitivne psihologije značajno povećao broj istraživanja fenomena koji uključuju pozitivna stanja, pozitivnu osobu i pozitivnu zajednicu (Rijavec i Miljković, 2006). Analiza je objavljenih znanstvenih radova u tom području pokazala da je najviše istraživanja provedeno o dobrobiti (preko 40\%), a slijede istraživanja snaga karaktera, nade, zahvalnosti, otpornosti i samorazvoja (Donaldson, Dollwet i Rao, 2015). Bez obzira na to što nije među najčešćim temama istraživanja, i stanje zanesenosti (engl. flow), kao jedno od pozitivnih stanja, također je privuklo veliku pozornost istraživača.

Majda Rijavec, Učiteljski fakultet Sveučilišta u Zagrebu, Savska cesta 77, 10000 Zagreb, Hrvatska. E-pošta: majda.rijavec@ufzg.hr 
Zanesenost je izrazito ugodno psihološko stanje koje ljudi doživljavaju kada su $\mathrm{u}$ tolikoj mjeri usmjereni na aktivnost kojom se trenutno bave da ih ta aktivnost $\mathrm{u}$ potpunosti zaokupi (Csikszentmihalyi, 1975/2000). To je stanje u kojem se pojedinac stapa s aktivnośću, potpuno je u nju uronjen, osjeća apsolutnu kontrolu nad njezinim izvođenjem, gubi osjećaj za vrijeme, a aktivnost postaje autotelična, tj. sama je sebi svrhom (Csikszentmihalyi i Rathunde, 1992; Nakamura i Csikszentmihalyi, 2009). Stanje zanesenosti je ugodno i zbog toga što je $u$ tom stanju kapacitet svijesti $u$ potpunosti usmjeren na aktivnost, pa pojedinac nema vremena za neugodne i anksiozne misli (Csikszentmihalyi, 1997).

Prema originalnom modelu zanesenosti (Csikszentmihalyi, 1975/2000) da bi došlo do stanja zanesenosti moraju biti zadovoljeni određeni uvjeti, od kojih je najvažniji postojanje ravnoteže između izazova koje aktivnost postavlja pred osobu i njezinih sposobnosti i vještina za izvođenje te aktivnosti. Preteški zadaci izazivaju anksioznost, dok prelaki zadaci za nečiju vještinu dovode do dosade. Ovaj je model kasnije dopunjen, kad je otkriveno da i izazovi i vještine moraju za pojedinca biti iznadprosječni (Delle Fave i Massimini, 1988, 1992; Massimini i Carli, 1988; Massimini, Csikszentmihalyi i Carli, 1987).

Bitno je, također, da su ciljevi u izvođenju aktivnosti neposredni i jasno definirani, da osoba može pratiti njihovo izvršavanje i da ima dobru sposobnost koncentracije. Kako je zanesenost iznimno ugodno iskustvo, ljudi su skloni (kada je to moguće) birati aktivnosti koje je izazivaju i ponavljati ih.

Kad su u pitanju situacije koje izazivaju zanesenost, postoje značajne individualne razlike, no kad je dožive, ljudi je opisuju na vrlo sličan način, neovisno o svojoj dobi, rodu, socioekonomskom statusu, državi ili kulturi u kojoj žive (Bassi i Delle Fave, 2004; Moneta, 2004). Nadalje, treba napomenuti da istraživači razlikuju trenutnu zanesenost, koja ovisi o okolnostima (zanesenost kao stanje), i sklonost doživljavanju zanesenosti, koja ovisi o osobinama ličnosti (zanesenost kao dispozicija) (Keller i Blomann, 2008; Mosing i sur., 2012; Ullen i sur., 2012). Dakle, zanesenost nije samo trenutno prolazno iskustvo nego sklonost doživljavanju zanesenosti ovisi i o individualnim razlikama, pa je uzimajući to u obzir Csikszentmihalyi (1997) uveo pojam "autotelične ličnosti". Tako bi autotelična osoba bila ona koja uživa u životu i bavi se određenim aktivnostima zato što doista u njima uživa, a ne zbog nekih vanjskih nagrada i ciljeva. Ovaj tip ličnosti ima neke metavještine ili kompetencije koje omogućuju osobi da lakše uđe u stanje zanesenosti i duže ostane u njemu. Tako ljudi koji su radoznali, uporni i manje usmjereni sami na sebe češće i intenzivnije doživljavaju zanesenost. U okviru se petofaktorskog modela ličnosti pokazalo da je otvorenost prema iskustvu najvažnija varijabla za razlikovanje adolescenata koji doživljavaju zanesenost (u socijalnoj domeni, produktivnim zadacima ili slobodnim aktivnostima) u odnosu na one koji ju ne doživljavaju (Bassi, Steca, Monzani, Greco i Delle Fave, 2014). Istraživanja u kojima je mjeren intenzitet zanesenosti doživljen kroz razne domene pokazala su, pak, pozitivnu povezanost sa savjesnošću, a negativnu sa neuroticizmom (Ullen i 
sur., 2012; Ullen, Harmat, Thorell i Madison, 2016), a istraživanja zanesenosti u akademskoj domeni pokazala su povezanost zanesenosti s perfekcionizmom (Ljubin Golub, Rijavec i Jurčec, 2018).

Zanesenost je najčešće istraživana u području slobodnih aktivnosti, koje uključuju različite igre, sport ili umjetnost (Delle Fave i Bassi, 2003; Hull, Williams i Griffiths, 2013; Swann, Keegaen, Piggott i Crust, 2012; Wrigley i Emmerson, 2013). To su aktivnosti koje ljudi sami biraju jer se žele kreativno izraziti i usavršiti svoje vještine. No stanje zanesenosti javlja se i u područjima ljudskog djelovanja, kao što su posao (Delle Fave i Massimini 2003, Olčar, Rijavec i Ljubin Golub, 2017) i obrazovanje (Bassi i Delle Fave, 2004; Rijavec, Ljubin Golub i Olčar, 2016; Shernoff i Csikszentmihalyi, 2009), u kojima pojedinci često moraju obavljati i aktivnosti koje su im nametnute ili u njima imaju manju slobodu izbora.

Od samog se početka istraživanja zanesenosti pretpostavljala njezina povezanost $\mathrm{s}$ postignućem $\mathrm{u}$ aktivnostima $\mathrm{u}$ kojima se doživljava (Engeser i Rheinberg, 2008). Ova se pretpostavka temelji na činjenici da je zanesenost visoko funkcionalno stanje koje bi samo po sebi trebalo doprinositi učinkovitosti. Drugo, budući da se radi o ugodnom iskustvu, osoba je motivirana za unapređivanje svojih vještina kako bi sebi mogla postaviti izazovnije ciljeve i tako ponovno doživjeti zanesenost. Pritom cilj osobe nije postizanje izvrsnosti zbog vanjskog vrednovanja, nego ovladavanje aktivnošću s ciljem ponovnog doživljavanja zanesenosti. No takva usmjerenost na aktivnost onda posljedično može dovesti i do izvrsnosti u toj aktivnosti. Istraživanja su potvrdila ovu pretpostavku. Tako su ljudi koji češće doživljavaju zanesenost uspješniji u sportu (npr. Bakker, Oerlemans, Demerouti, Bruins Slot i Karamat Ali, 2011), glazbi i umjetnosti (Butkovic, Ullén i Mosing, 2015; Csikszentmihalyi i LeFevre, 1989), na poslu (npr. Demerouti, 2006; Salanova, Bakker i Llorens, 2006), u školovanju (Carli, Delle Fave i Massimini, 1988) i u različitim drugim aktivnostima, poput šaha, ekstremnog penjanja i plesa (Csikszentmihalyi, 1975/2000).

Do danas je razvijeno više metoda za mjerenje zanesenosti, a većina se temelji na samoiskazima pojedinaca o vlastitim iskustvima i karakteristikama okruženja (za pregled vidi Delle Fave, Massimini i Bassi, 2011; Moneta, 2012). Neke od metoda traže retrospektivnu evaluaciju zanesenosti, dok su druge usmjerene na ispitivanje zanesenosti u realnom vremenu. U samom su početku istraživanja zanesenosti uglavnom bila kvalitativnog tipa. Korišteni su intervjui u kojima se od ljudi tražilo da opišu svoja subjektivna stanja u situacijama kad su bili potpuno zaokupljeni nekom aktivnošću u kojoj su uživali (Csikszentmihalyi, 1975/2000). Kasnije su razvijene upitničke mjere koje se odnose na različite aspekte zanesenosti, kao što je njezina učestalost ili uvjeti u kojima se pojavljuje. Neka istraživanja uključuju i opsežnije metode prikupljanja podataka u realnom vremenu doživljavanja zanesenosti, poput metode uzorkovanja iskustva (engl. Experience Sampling Method, ESM), koju su razvili Csikszentmihalyi, Larson i Prescott (1977). U istraživanjima koja se koriste ovom metodom sudionici nose elektroničku napravu 
(sat, dlanovnik, mobitel) koja im nekoliko puta dnevno šalje signal, a oni tada trebaju procijeniti vrstu i kvalitetu trenutnog iskustva. Najčešće se signali šalju slučajnim rasporedom (engl. Signal-contingent sampling), ali mogu se slati i u unaprijed definiranim vremenskim intervalima (engl. Interval-contingent sampling) ili vezano uz neku specifičnu situaciju ili događaj (engl. Event-contingent sampling). Broj i raspored signala varira od istraživanja do istraživanja, no obično iznosi 6-8 signala dnevno tijekom jednog tjedna, što je dovoljno da se prikupi reprezentativan uzorak iskustava (Hektner, Schmidt i Csikszentmihalyi, 2007).

\section{Važnost zanesenosti u obrazovnom kontekstu}

Većina je učenika i studenata bar jednom u životu doživjela zanesenost u nekoj aktivnosti, no manji je dio njih doživio zanesenost prilikom neke akademske aktivnosti, kao što je učenje (Asakawa, 2010; Bakker, Ljubin Golub i Rijavec, 2017; Shernoff i Csikszentmihalyi, 2009).

Dosadašnja su istraživanja većinom provedena na srednjoškolcima i pokazala su da učenici općenito zanesenost češće doživljavaju u neakademskom području nego u akademskim predmetima, poput engleskog jezika ili matematike (za pregled vidi Shernoff i Csikszentmihalyi, 2009). Istraživanja provedena metodom uzorkovanja iskustva pokazala su da se od ukupnog broja situacija u kojima učenici doživljavaju zanesenost 36.6\% situacija odnosi na učenje (Delle Fave i Bassi, 2000), te da zanesenost učenici mogu doživjeti za vrijeme školskog rada (npr. Bassi i Delle Fave, 2012), kao i kada uče kod kuće (Bassi i Delle Fave, 2004). Doživljavanje je zanesenosti često povezano s učenjem za neko natjecanje ili za test, odnosno s time da učenici imaju neki konkretan cilj (Choe, Kang, Seo i Yang, 2015).

Istraživanja učestalosti akademske zanesenosti na studentskim uzorcima također pokazuju da je stanje zanesenosti češće u neakademskom području, no određen broj studenata doživljava takvo stanje i u akademskim aktivnostima. To pokazuju i istraživanja provedena u Hrvatskoj. Primjerice, na uzorku od 174 studentice učiteljskog studija njih $73 \%$ izjavilo je da doživljava zanesenost vrlo često ili uvijek u neakademskim aktivnostima, dok je zanesenost u pojedinim akademskim aktivnostima doživjelo između 20\% (tijekom predavanja) do najviše 52\% (tijekom različitih obveznih zadataka) studentica (Rijavec i sur., 2016). Slično tome, u istraživanju na hrvatskim studentima provedenom na 394 studenta različitih studijskih programa samo je 38\% studenata navelo da su doživjeli zanesenost tijekom učenja (Bakker i sur., 2017).

Bez obzira na njezinu manju učestalost zanesenost je u akademskom kontekstu važna iz više razloga. Kao prvo, određen broj studenata napusti studij, što može imati negativne posljedice po njih, njihove obitelji, ali i na cijelo društvo. To je problem i u svijetu, a kad je u pitanju visoko obrazovanje, hrvatski studenti u većoj mjeri napuštaju studij (preko 40\%) nego što je to slučaj u ostalim zemljama EU-a (File, Farnell, Doolan, Lesjak i Śćukanec, 2013). Većina studenata odustane već u 
početnim godinama studija. Iako veći broj istraživanja upućuje na važnost pohađanja nastave na fakultetu, mnogi studenti dosta izostaju, i to često zbog dosade ili opće nezainteresiranosti (Rijavec i Miljković, 2015). Dosadašnja su istraživanja pokazala da je i kod adolescenata i kod visokoškolskih studenata akademska zanesenost povezana s višom razinom predanosti školovanju (Csikszentmihalyi, Rathunde i Whalen, 1993).

Drugi razlog leži u činjenici da završetkom studija ne prestaje potreba za učenjem, pogotovo u današnjem svijetu, gdje je cjeloživotno učenje imperativ. Povezivanje učenja sa stanjem zanesenosti može pomoći i učenicima i studentima da se bolje pripreme za izazove novih učenja koji ih čekaju u svijetu rada. Učenje može biti vrlo značajan izvor zaokupljenosti, osobnog zadovoljstva i osjećaja smisla, a stanje zanesenosti u učenju može olakšati stjecanje novog znanja i aktivno sudjelovanje u zajednici. Komentirajući situaciju u današnjem obrazovanju, Larson (2000) navodi da je nužno postići da mladi budu motivirani i entuzijastični kad je u pitanju učenje jer će jedino tako razviti vještine koje su im u 21. stoljeću neophodne da bi dobro funkcionirali kao odrasli ljudi i preuzeli odgovornost za svoje ponašanje i svoj život. Kako ćemo to postići ako učenje u školi i na fakultetu bude dosadno i nedovoljno izazovno? Upravo istraživanja zanesenosti u akademskom kontekstu i njihova primjena mogli bi u tome pomoći.

Treći je razlog veza između zanesenosti i akademskog uspjeha. Naime, dosadašnja su istraživanja pokazala postojanje veze između akademske zanesenosti i različitih obrazovnih ishoda. Tako se pokazalo da je kod adolescenata i visokoškolskih studenata zanesenost povezana s boljim svladavanjem nastavnog programa (Csikszentmihalyi i sur., 1993) i s višom razinom obrazovnih ishoda (Rossin, Ro, Klein i Guo, 2009; Shernoff, Csikszentmihalyi, Schneider i Shernoff, 2003). Primjerice, studenti nadareni za matematiku koji su u prvom dijelu kolegija češće doživljavali zanesenost, bili su uspješniji u zadacima iz matematike i u drugom dijelu (Heine, 1996). To se pokazalo točnim i za studente $u$ drugim predmetima $u$ kojima nisu bili daroviti (Engeser, Rheinberg, Vollmeyer i Bischoff, 2005). Istraživanja u okviru e-učenja također pokazuju da je zanesenost povezana s boljim uratkom u učenju (Choi, Kim i Kim, 2007; Ho i Kuo, 2010). Na uzorku se hrvatskih studenata pokazalo da su iskustva zanesenosti u učenju na studiju pozitivno povezana $\mathrm{s}$ akademskim postignućem izraženim kao prosječnom ocjenom u studiranju (Ljubin Golub i sur., 2016).

I na kraju, ocjene, uspjeh na ispitima i pravovremeno završavanje škole i fakulteta sigurno su vrlo važni i povezani s dobrobiti na svim obrazovnim razinama (El Ansari i Stock, 2010; Gilman i Huebner, 2003). No akademski uspjeh nije jedini element života učenika i studenata. Kvaliteta iskustava u školi i na fakultetu sigurno je važna varijabla sama po sebi, pa bi pozitivna iskustva poput akademske zanesenosti trebala biti među kriterijima za evaluaciju poučavanja i akademskog okruženja (Schiefele i Csikszentmihalyi, 1995). Primjerice, Klein, Rossin, Guo i Ro (2010) mjerili su zanesenost za vrijeme nastave iz menadžmenta te našli da je 
povezana sa studentskom percepcijom napretka u učenju i stjecanju vještina $\mathrm{i}$ zadovoljstvom nakon održanog sata. Dakle, osim što je doživljavanje zanesenosti u akademskim aktivnostima važno za bolje obrazovne ishode te pozitivno iskustvo učenja, može se zaključiti da je jednako tako važno i za dobrobit učenika i studenata (Moneta, 2004).

Uzimajući u obzir sve navedeno, proizlazi da bi bilo vrijedno poticati doživljavanje zanesenosti u obrazovnom kontekstu. Slijedom toga, od interesa su istraživanja koja bi pružila nove spoznaje o navedenom. No dosadašnja su istraživanja većinom bila usmjerena na zanesenost $u$ aktivnostima koje se odvijaju u slobodnom vremenu i na poslu, dok je zanesenost u obrazovnom kontekstu nešto rjeđe ispitivana, posebno na studentima u visokom obrazovanju.

Jedno su od tih rijetkih istraživanja proveli Steel i Fullagar (2009), u kojem su ustanovili da je zanesenost $\mathrm{u}$ akademskim aktivnostima povezana s psihološkom dobrobiti, a preko toga i s fizičkim zdravljem. U istraživanju koje je provela Lee (2005) pokazalo se da je doživljavanje akademske zanesenosti negativno povezano s prokrastinacijom, odnosno da studenti koji rjeđe doživljavaju zanesenost u učenju više odgađaju svoje akademske obveze. Detaljnije, studenti koji nisu imali jasne ciljeve i koji se nisu usredotočili na zadatak bili su skloni prokrastinaciji. Posebno je važan nalaz iz istog istraživanja bio da se prokrastinacija studenata može objasniti prvenstveno (manjim) iskustvom zanesenosti, a ne motivacijom i nedostatkom intrinzične motivacije.

Istraživanje karakteristika studenata pokazalo je da je sklonost doživljavanju akademske zanesenosti povezana s višom razinom adaptivnog perfekcionizma (definiranog $\mathrm{u}$ terminima visokih standarda), dok je negativno povezana $\mathrm{s}$ maladaptivnim perfekcionizmom (definiranim kao opaženom razlikom između vlastita učinka i postavljenih standarda) (Ljubin Golub i sur., 2018). Također, istraživanje Millsa i Fullagara (2008) pokazalo je da zanesenost češće doživljavaju studenti s većom intrinzičnom motivacijom i visokom potrebom za autonomijom.

\section{Karakteristike akademskih aktivnosti koje izazivaju zanesenost}

Imajući u vidu navedenu važnost akademske zanesenosti poznavanje karakteristika akademskih aktivnosti koje u najvećoj mjeri izazivaju zanesenost može biti i od teorijske i od praktične važnosti.

Prvo, na uzorku se hrvatskih studenata pokazalo da su studenti najčešće doživljavali zanesenost tijekom pripreme za različite obvezne zadatke (52.3\%), slijedi zanesenost tijekom seminara (32.7\%) i pripreme za ispit (32.7\%). Najmanji je broj studenata doživljavao zanesenost za vrijeme predavanja (19.6\%) (Rijavec i sur., 2016). Dakle, može se zaključiti da su akademske aktivnosti koje potiču doživljavanje zanesenosti one koje traže aktivno učenje, kakvo je prisutno primjerice tijekom pripreme za različite obvezne zadatke, odnosno kakvo je najmanje prisutno za vrijeme predavanja. Slični su podaci dobiveni u istraživanju zanesenosti kod 
talijanskih srednjoškolaca, gdje se pokazalo da su domaće zadaće češće bile povezane sa zanesenošću, dok je rad u školi češće bio povezan sa stanjem apatije (Delle Fave, 1996). Pretpostavka je da pasivno slušanje predavanja, koje najčešće karakterizira i srednjoškolsku i visokoškolsku nastavu, ne predstavlja dovoljan izazov za učenike i studente, i time onemogućava stanje zanesenosti. Slične su rezultate dobili Shernoff i suradnici (2003), koji su pokazali da je veća zanesenost bila u situacijama rada u grupi nego kad su učenici slušali predavanje, gledali film ili rješavali ispitne zadatke.

Drugo, već ranije spomenuto istraživanje Steela i Fullagara (2009) uputilo je na dva važna čimbenika koji facilitiraju doživljavanje akademske zanesenosti: podržavanje autonomije studenata od strane profesora te jasnoća uloge, odnosno student mora točno znati što treba raditi, a u sklopu jasnoće uloge važne su i povratne informacije profesora, što se objašnjava time da oba navedena čimbenika povećavaju osjećaj kontrole (Csikszentmihalyi, 1997). Culbertson, Fullagar, Simmons i Zhu (2015) proveli su istraživanje o ulozi materijala koji je prezentiran studentima, pri čemu su studenti procjenjivali zanesenost nakon svakog sata nastave tijekom dva tjedna koliko je trajala nastava. Pokazalo se da je za doživljavanje zanesenosti na satu važan prediktor bilo razumijevanje materijala koji im je prezentiran kao i to koliko je materijal bio studentima zanimljiv.

Navedena su istraživanja pokazala da su aktivno učenje, zainteresiranost $\mathrm{i}$ visoka uključenost učenika/studenata poticajni za doživljavanje akademske zanesenosti. Detaljniji uvid u to kojim se specifičnim kognitivnim aktivnostima učenici i studenti pritom koriste može ponuditi pristup temeljen na konceptu samoregulacije učenja (Pintrich, 2004) u okviru kojega se istražuju metakognitivne i kognitivne strategije koje studenti rabe prilikom učenja. Takvo je istraživanje provela Ljubin Golub (2014) s ciljem utvrđivanja povezanost korištenja kognitivnih i metakognitivnih strategija s doživljavanjem zanesenosti u učenju. Rezultati su regresijskih analiza pokazali da je od šest kognitivnih strategija (organizacija prepoznavanjem najvažnijeg sadržaja, organizacija sažimanjem sadržaja, povezivanje, kritičko dokazivanje, učenje napamet i ponavljanje) kritičko dokazivanje bilo jedini značajan prediktor zanesenosti u učenju. Kritičko dokazivanje uključuje razmišljanje o mogućim alternativama tvrdnji ili zaključaka u sadržaju koji student uči, razvijanje svojih ideja na temelju tog sadržaja ili razjašnjavanje proturječnih iskaza. Od metakognitivnih strategija najvažniji prediktor zanesenosti u učenju i akademskim zadacima bilo je samonadgledanje. Samonadgledanje uključuje, primjerice, postavljanje pitanja kako bi student provjerio je li doista sve razumio ili obrađivanje dodatnih zadataka s istom svrhom. Očito je da su i kritičko dokazivanje i samonadgledanje izazovne aktivnosti koje studentima koji ih koriste omogućuju češće stanje zanesenosti.

Posve drugačiji pristup istraživanju karakteristika akademskih aktivnosti povezanih sa zanesenosti imale su Rijavec i Belina (2017), koje su provele kvalitativno istraživanje na studentima treće i pete godine učiteljskog studija. 
Studentima su prezentirana tri zorna opisa iskustva zanesenosti prenesena iz originalnih intervjua o zanesenosti (Csikszentmihalyi i Csikszentmihalyi, 1988). Nakon toga su se studenti trebali sjetiti jedne aktivnosti vezane uz studiranje koja im je u najvećoj mjeri izazvala takvo iskustvo (predavanja, seminari, vježbe, učenje za ispit, priprema seminara, priprema izlaganja i sl.) te opisati što detaljnije tu aktivnost (Kada ste doživjeli to iskustvo? Što ste točno radili? Gdje ste bili? Uz koji je kolegij aktivnost bila vezana? Koje su karakteristike zadatka ili situacije doveli do takvog iskustva?). Prvi je glavni nalaz ovog istraživanja bio da stariji studenti (peta godina) značajno više od studenata treće godine izjavljuju da su u nekoj akademskoj aktivnosti doživjeli zanesenost (77\% nasuprot 44\%). Drugi je glavni nalaz bio da različite akademske aktivnosti izazivaju zanesenost kod studenata na trećoj u odnosu na studente pete godine. Naime, nakon analize odgovora zaključeno je da kod studenata treće godine zanesenost najčešće izazivaju različite specifične umjetničke aktivnosti, dok su na drugom mjestu aktivnosti vezane uz učenje i pripremu za ispite. Za razliku od toga, kod studenata pete godine zanesenost je bila najčešće izazvana pripremom za održavanje javnog sata i njegovim održavanjem. Ostale su akademske aktivnosti navođene u značajno manjoj mjeri. Ovakvi rezultati podržavaju pretpostavku da se u akademskim aktivnostima zanesenost događa to češće što je ta aktivnost značajnija za ostvarenje važnih ciljeva studenata. Na trećoj je godini studija (uz različite specifične umjetničke aktivnosti) polaganje ispita sigurno među najvažnijim aktivnostima jer o tome ovisi nastavak studija, dok su na petoj godini od izrazite važnosti javni satovi, odnosno prve provjere stečenih vještina u praksi.

Za sudionike je u našim istraživanjima pripadnost akademskoj zajednici (tj. skupini studenata) sigurno jedna od glavnih odrednica njihova socijalnog identiteta. Istraživanja pokazuju da su studenti više angažirani u akademskom procesu ako identitet "studenta" postane dio njihova pojma o sebi (Osbourne i Jones, 2011). Na trećoj je godini studija jedan od važnih elemenata identiteta studenta sigurno uspješno polaganje ispita, pa je možda zbog toga i zanesenost u učenju i pripremama za ispit vrlo visoka. Kod studenata na petoj godini studija, zbog velikog broja javnih satova za koje se moraju pripremiti i održati ih, to možda postaje važniji dio njihova studentskog identiteta, pa je onda i zanesenost u takvim aktivnostima najčešća.

Jedan je pravac $u$ istraživanjima zanesenosti u obrazovanju (koji ima veze $s$ karakteristikama akademskih situacija) fokusiran na upotrebu multimedija u učenju kako bi se povećala razina zainteresiranosti učenika. Odnosno, koristi se učenje putem edukacijskih igara u kojima osoba, osim što igra digitalnu igru, kroz tu igru uči i primijenjuje neki sadržaj. Budući da se takvo učenje koristi računalnim igricama koje su po prirodi zanimljive, zabavne i motivirajuće, pokazalo se da takvo virtualno okruženje za učenje potiče doživljavanje zanesenosti (Choi i Baek, 2011). Simulacijske igre ne samo da mogu povećati iskustvo zanesenosti i kod studenata (Chang, Liang, Chou i Lin, 2017; Kiili, de Freitas, Arnab i Lainema, 2012) nego dovode i do boljeg usvajanja sadržaja (Admiraal, Huizenga, Akkerman i Dam, 2011). 
Ne treba zanemariti da se većina akademskih aktivnosti na fakultetu događa pod vodstvom visokoškolskih nastavnika, tako da osim karakteristika akademskih aktivnosti koje izazivaju zanesenost, treba imati na umu i karakteristike nastavnika. Istraživanja pokazuju da zanesenost učitelja, kao i percepcija zanesenosti drugih studenta, utječe na zanesenost učenika i studenata (Bakker, 2005; Culbertson i sur., 2015). S druge strane, zanesenost učenika i studenata povratna je informacija koja najviše utječe na zadovoljstvo nastavnika (Delle Fave i Massimini, 2003). Tako neki autori govore da se tu radi o "spirali prema gore" - zanesenost učitelja potiče zanesenost učenika, a učenička je zanesenost važna pozitivna povratna informacija učiteljima (Salanova, Bakker i Llorens, 2006).

\section{Akademska zanesenost i dobrobit studenata}

Teoretičari u području pozitivne psihologije navode dobrobit kao jedan od važnih kriterija pozitivnog funkcioniranja osobe, a dobrobit se općenito smatra i važnim životnim ciljem (Seligman i Csikszentmihalyi, 2000). Pa tako, kao što je već navedeno, i u području obrazovanja akademski uspjeh nije jedini cilj, nego su važni i kvaliteta iskustava na fakultetu kao i dobrobit studenata.

Suvremena se istraživanja dobrobiti uglavnom temelje na dva glavna pristupa, hedonističkom i eudaimonističkom. Hedonistički je pristup usmjeren na visoku razinu životnog zadovoljstva te visoku razinu pozitivnih i nisku razinu negativnih emocija (Kahneman, Diener i Schwartz, 1999), dok je eudamonistički pristup (Waterman, 1993) usmjeren na smisao i samoostvarenje. Na određeni način teorija zanesenosti sintetizira hedonistički i eudamonistički pristup dobrobiti (Moneta, 2004). S jedne strane, zanesenost je ugodno stanje te stoga utječe na trenutni osjećaj sreće i tako povećava hedonističku dobrobit. $\mathrm{S}$ druge strane, utječe i na eudamonističku dobrobit time što povećava motivaciju osobe za izvršavanjem izazovnih zadataka, čime potiče njezin dugoročni osobni razvoj. Što češće i intenzivnije osoba doživljava stanje zanesenosti, to je sretnija i, u konačnici, bolje ostvaruje svoje potencijale. Kako se smatra da u stanju zanesenosti osoba maksimalno upotrebljava svoje kapacitete (Nakamura i Csikszentmihalyi, 2009), u tom bi se smislu doživljaj zanesenosti mogao smatrati optimalnim stanjem za realiziranje postojećih vještina, ali i stanjem koje može potpomoći razvoj potencijala osobe. Naime, kako napreduju u nekoj vještini, ljudi moraju tražiti sve složenije izazove ako žele ponoviti stanje zanesenosti, a time u svijest uvode nove elemente, informacije i zapažanja iz prethodno izvršene aktivnosti. Tako razvijaju svoje potencijale, a, u konačnici, i eudamonističku dobrobit. Na to upućuju i Moneta i Csikszentmihalyi (1996) kada definiraju zanesenost "kao psihološko stanje u kojem se osoba istovremeno osjeća kognitivno učinkovitom, motiviranom i sretnom" (str. 277), kao i Csikszentmihalyi (1997), koji navodi da zanesenost omogućava osobi da ostvari svoje potencijale. 
Dosadašnja istraživanja potvrđuju ovu teorijsku povezanost između stanja zanesenosti i dobrobiti. Ljudi koji češće doživljavaju zanesenost sretniji su, opušteniji i zainteresiraniji (Clarke i Haworth, 1994; Ishimura i Kodama, 2006). Primjerice, istraživanje o stanju zanesenosti kod japanskih studenata (Asakawa, 2010) pokazalo je da $27.3 \%$ studenata nije nikad doživjelo to stanje, $20 \%$ doživljavalo je zanesenost nekoliko puta godišnje, $30.1 \%$ jednom mjesečno, a samo $1.2 \%$ studenata više od jednom dnevno. Oni koji su češće doživljavali zanesenost (u raznim domenama života) imali su veće samopoštovanje, nižu anksioznost, bili su skloniji koristiti aktivno suočavanje sa stresom, te imali veći osjećaj ispunjenja i zadovoljstva u životu.

Međutim, iako postoje dokazi o povezanosti zanesenosti i dobrobiti, postavlja se pitanje u kojoj je mjeri doživljavanje zanesenosti u specifičnim područjima povezano s dobrobiti studenata, odnosno koja je uloga zanesenosti u akademskom području u odnosu na stanja zanesenosti u drugim područjima života. Naime, zanesenost sama po sebi ne dovodi nužno do pozitivnih posljedica kao što su razvoj i dobrobit, nego može dovesti i do nepoželjne ovisnosti, kao što je zanesenost $u$ području upotrebe interneta i videoigara (Yang, Lu, Wang i Zhao, 2014). Čak i kad je aktivnost u kojoj se doživljava zanesenost poželjna i produktivna, hoće li zanesenost u toj aktivnosti dovesti do razvoja i dobrobiti osobe, ovisi o ulozi koju ta aktivnost ima u vrijednosnom sustavu osobe i kulture u kojoj živi (Delle Fave, 2009).

Već navedeno istraživanje Steela i Fullgara (2009) pokazalo je važnost akademske zanesenosti za dobrobit studenta. Uz to, do danas je provedeno nekoliko istraživanja koja su pokušala odgovoriti na pitanje koliko je zanesenost studenata u akademskim aktivnostima važna za njihovu dobrobit $u$ odnosu na zanesenost $u$ drugim područjima života. U jednom je istraživanju na hrvatskim studentima (Rijavec i sur., 2016) zanesenost procjenjivana prilagođenim Upitnikom zanesenosti (Flow Questionnaire, FQ, Csikszentmihalyi, 1975/2000). Studenti su zamoljeni da pročitaju opise iskustva zanesenosti (npr. "Moj um ne luta. Ne mislim ni na što drugo. U potpunosti sam obuzet onim što radim..."), i procijene koliko često su doživjeli takva iskustva u pet različitih aktivnosti iz akademske domene (priprema za ispit, predavanja, seminari, pripremanje različitih obveznih zadataka, druge aktivnosti vezanih uz fakultet) te $\mathrm{u}$ aktivnostima nevezanim za fakultet $\mathrm{tj}$. $\mathrm{u}$ neakademskoj domeni. Regresijska analiza pokazala je da je od navedenih iskustava zanesenosti doživljenim u različitim aktivnostima jedini značajan prediktor dobrobiti bila zanesenost doživljena tijekom priprema za ispite. Pritom su kao indikatori dobrobiti mjereni životno zadovoljstvo i psihološki procvat (engl. flourishing). Studenti koji doživljavaju zanesenost tijekom priprema za ispite imali su višu razinu dobrobiti (Rijavec i sur., 2016). Kako se to može objasniti? Autori su ponudili objašnjenje da je samo zanesenost doživljena u za studente važnim aktivnostima povezana $s$ dobrobiti. Budući da priprema za ispite ima značajne posljedice za studente, ona im je vjerojatno važnija aktivnost od pohađanja predavanja ili neakademskih aktivnosti. 
Pretpostavka da je zanesenost $\mathrm{u}$ akademskom području važnija za dobrobit studenata od zanesenosti u aktivnostima u slobodnom vremenu, jer su akademske aktivnosti važnije i korisnije za njihove buduće ciljeve, potvrđena je u drugom istraživanju (Rijavec, Ljubin Golub, Jurčec i Olčar, 2017). Studenti su procjenjivali koliko su često doživjeli zanesenost u raznim područjima na skali od 1 (nikad) do 5 (uvijek), a uz to su procjenjivali koliko su im navedena područja važna i koliko su korisna za njihove buduće ciljeve. Sukladno ranijim nalazima (Rijavec i sur., 2016) istraživanje je pokazalo da je zanesenost kod studenata najčešća u području slobodnih aktivnosti, odnosno prisutna gotovo uvijek, slijedi zanesenost u rutinskim poslovima, a najmanje je učestala u akademskom području, za koju je učestalost procjenjena oko teorijske sredine skale (prosječne su vrijednosti za cijeli uzorak bile $4.29,3.86$ i 3.54 za zanesenost u slobodnim aktivnostima, rutinskim poslovima te akademskom području). Najvažnijima i najkorisnijima procjenjivane su akademske aktivnosti, slijedile su aktivnosti u slobodno vrijeme, dok su na zadnjem mjestu po procjenjenoj važnosti i korisnosti bili kućanski i ostali rutinski poslovi. Rezultati su pokazali da je zanesenost u akademskom području bila najvažniji prediktor dobrobiti, slijedila je zanesenost $\mathrm{u}$ aktivnostima u slobodno vrijeme, dok zanesenost u kućanskim i ostalim rutinskim poslovima nije bila povezana s dobrobiti. Time je potvrđena hipoteza o različitoj ulozi zanesenosti za dobrobit studenata, ovisno o važnosti/korisnosti aktivnosti u kojoj se zanesenost doživljava: zanesenost $u$ nevažnim područjima manje je važna za dobrobit, dok zanesenost doživljena u važnim aktivnostima značajno doprinosi dobrobiti studenata.

Ova veza između važnosti područja u kojem se zanesenost doživljava i dobrobiti potvrđena je i u istraživanju u kojem je u sklopu šireg longitudinalnog istraživanja ESM metodom mjerena trenutna zanesenost, trenutna sreća i zadovoljstvo (Olčar i Jurčec, 2017). Ispitanici su tijekom šest uzastopnih dana svakodnevno dobivali četiri signala raspoređena slučajnim rasporedom u različita vremena. Po dobivanju su signala navodili aktivnost kojom se trenutno bave te procjenu korisnosti i važnosti uspjeha u toj aktivnosti. Osim toga, procjenjivali su trenutnu zanesenost te stupanj trenutne sreće i zadovoljstva. Pokazalo se da je zanesenost bila najčešća tijekom aktivnosti u slobodno vrijeme, dok u učestalosti zanesenosti u učenju i zanesenosti u rutinskim aktivnostima nije bilo razlike. Potvrđeni su nalazi iz prethodnih istraživanja da su studentima akademske aktivnosti važnije i korisnije od aktivnosti koje provode u slobodno vrijeme i od rutinskih aktivnosti. U svim je kontekstima zanesenost bila značajan prediktor trenutne dobrobiti, ali je povezanost trenutne zanesenosti s trenutnom dobrobiti bila veća tijekom učenja nego tijekom slobodnog vremena i rutinskih aktivnosti.

Dakle, iako su ranija istraživanja pokazala povezanost zanesenosti u učenju s obrazovnim rezultatima (Engeser i Rheinberg, 2008), tek su rezultati prethodno opisanih istraživanja uputili i na važnost akademske zanesenosti za dobrobit studenata, posebno ako je zanesenost doživljena u akademskim aktivnostima važnim za dugoročne ciljeve studenata. 
U prethodno navedenim istraživanjima koja su pružila dokaze o povezanosti akademske zanesenosti i dobrobiti kao pokazatelji dobrobiti korišteni su pozitivni indikatori, kao što su zadovoljstvo životom i psihološki procvat. Međutim, o dobrobiti se studenata može zaključiti i preko negativnih indikatora, kao što su stres i sagorijevanje, koji upućuju na smanjenje psihološke dobrobiti. Kao što je već navedeno, u stanju zanesenosti potpuni je kapacitet svijesti usmjeren na aktivnost, te osoba nema vremena za neugodne $i$ anksiozne misli, pa bi zanesenost mogla djelovati kao zaštitni čimbenik u smanjenu stresa. Postojanje je stresa i sagorijevanja kod studenata pokazano u više istraživanja (pr. Dyrbye i sur., 2010; Pöhlmann, Jonas, Ruf i Harzer, 2005). Štoviše, neki istraživači smatraju da akademsko postignuće bez istinske uključenosti studenata (koja je bliska zanesenosti) dovodi do stresa i sagorijevanja (Conner, Pope i Galloway, 2009). Kako su upravo akademski stresori kod većine studenata najčešći (Pöhlmann i sur., 2005), to bi bilo moguće očekivati da bi smanjenje akademskog stresa zbog češćeg stanja zanesenosti moglo značajno pridonijeti dobrobiti studenata.

Međutim, odnos je akademske zanesenosti sa stresom i sagorijevanjem kompleksan. S jedne strane, po definiciji, stanje zanesenosti ne događa se u situacijama kad osoba osjeća anksioznost zbog prevelikih izazova ili kad je pod stresom. Dakle, anksioznost i stres smatraju se kontraproduktivnim za iskustvo zanesenosti. No, isto tako, stanje zanesenosti, s obzirom na to da je ugodno i povezano $\mathrm{s}$ isključenjem svijesti iz aktualnih problema te posvemašnjom apsorpcijom u aktivnost, moglo bi biti ljekovito i pridonositi smanjenju doživljaja stresa i sagorijevanja. Zanesenost bi u akademskim aktivnostima mogla biti mehanizam koji studentima omogućuje uživanje i zaokupljenost, osjećaj kompetentnosti, odmak od svakodnevnih problema u studiranju i privatnom životu, a time i smanjenje stresa.

No, općenito vrlo su rijetka istraživanja koja su se bavila mogućnošću da zanesenost može pridonijeti smanjenju stresa i sagorijevanja. Jedno su od takvih istraživanje koje se odnosi na zanesenost na poslu proveli Lavigne i suradnici (Lavigne, Forest i Crevier-Braud, 2012). To je istraživanje sugeriralo da je zanesenost na poslu medijator između harmonične strasti i manjeg sagorijevanja na poslu, odnosno da harmonična strast za poslom dovodi do veće zanesenosti na poslu, a ovo, pak, do manjeg sagorijevanja na poslu.

$\mathrm{U}$ akademskom su kontekstu istraživanje medijatorne uloge akademske zanesenosti proveli Ljubin Golub, Olčar i Rijavec (2014) uklopivši hipotezu o negativnoj povezanosti akademske zanesenosti i sagorijevanja u kontekst teorije samoodređenja (Deci i Ryan, 1985). Istraživanje je potvrdilo pretpostavku o negativnoj vezi akademske zanesenosti i akademskog sagorijevanja (Ljubin Golub i sur., 2014). Osim toga, u skladu s teorijom samoodređenja (Deci i Ryan, 1985), pokazalo se da studenti koji percipiraju veću podršku autonomiji od svojih nastavnika imaju višu razinu autonomne motivacije i skloniji su doživljavanju akademske zanesenosti. Odnosno, akademska je zanesenost imala medijatornu ulogu 
između povećane autonomne motivacije i manjeg sagorijevanja studenata (Ljubin Golub i sur., 2014). Ovaj je nalaz o negativnoj vezi akademske zanesenosti i sagorijevanja potvrđen u već spomenutom istraživanju (Rijavec i sur., 2017) u kojem se pokazalo da je samo (manja) zanesenost $u$ akademskim aktivnostima bila značajan faktor u objašnjenju akademskog sagorijevanja, dok zanesenost koju su studenti doživljavali $\mathrm{u}$ drugim područjima života (zanesenost $\mathrm{u}$ rutinskim aktivnostima, zanesenost $\mathrm{u}$ slobodnim aktivnostima i zanesenost na poslu) nije bila povezana $\mathrm{s}$ manjim sagorijevanjem.

Zaključno se može reći da do sada provedena istraživanja pokazuju da je zanesenost $\mathrm{u}$ akademskim aktivnostima kod studenata manje učestala nego zanesenost u ostalim područjima njihova života, no veza je akademske zanesenosti i dobrobiti jača nego što je veza između zanesenosti i dobrobiti u drugim područjima. Navedena istraživanja sugeriraju da je to zbog toga što su akademske aktivnosti važnije za ostvarenje važnih životnih ciljeva nego što su to aktivnosti koje se provode u slobodno vrijeme (Rijavec i sur., 2017). Diplomirati i pronaći svoje mjesto u profesionalnom životu sigurno je za studente jedan od središnjih životnih ciljeva.

Chekola (2007) navodi da sreća proizlazi iz globalne životne perspektive osobe, što uključuje postojanje nekih općih životnih ciljeva. Ti ciljevi moraju biti sveobuhvatni, važni i trajni. Ako osoba uspije postaviti takve ciljeve i usmjeriti se na njihovo ostvarenje, moguće je da će to rezultirati osjećajem eudamonijske sreće ili opće zanesenosti. U istraživanju se portugalskih adolescenata pokazalo da su slobodne aktivnosti najveći izvor zanesenosti (55\%) u odnosu na samo $15 \%$ kad su u pitanju bile akademske aktivnosti. Shodno tome, adolescenti su preferirali slobodne aktivnosti, ali samo u kontekstu sadašnjosti. Kada se od njih tražilo da razmišljaju o svojim budućim životnim ciljevima, preferirali su učenje (Freire, Tavares, Silva i Teixeira, 2016). Također, zanesenost u nekoj aktivnosti može biti dobar prediktor budućih ciljeva i unapređivanja vještina u toj aktivnosti (Greene i Miller, 1996), a slijedom toga, i izbora zanimanja i životnih ciljeva (Delle Fave i Bassi, 2000).

\section{Praktične implikacije}

Navedena istraživanja imaju i neke praktične implikacije za visokoškolsko obrazovanje. Ako je zanesenost u akademskim aktivnostima manje učestala, ali važnija za dobrobit studenata, onda bi trebalo uložiti dodatne napore u kreiranje i organiziranje akademskih aktivnosti koje imaju veći potencijal za izazivanje zanesenosti. Iako istraživači na zanesenost gledaju i kao na opću sklonost i kao na trenutno stanje, istraživanja pokazuju da se u obveznim aktivnostima (kao što je, primjerice, posao) najveći dio stanja zanesenosti može pripisati situacijskim faktorima (Fullgar i Kelloway, 2009). Slične su rezultate dobile Zager Kocjan i Avsec (2017). U njihovu istraživanju u kojem su sudjelovali i zaposlenici i studenti zanesenost je u najvećoj mjeri bila povezana s karakteristikama situacije definiranim 
kao intelekt i pozitivnost. Intelekt se odnosio na percepciju intelektualne uključenosti, kognitivnih zahtjeva, dubokog razmišljanja i pokazivanja svojih intelektualnih sposobnosti u danoj situaciji. Pozitivnost je odražavala stupanj u kojem je situacija bila ugodna, jednostavna, jasna i sudionici su u njoj uživali.

Ova istraživanja upućuju na mogućnost da studenti koji inače ne bi doživjeli zanesenost $u$ nekoj akademskoj aktivnosti mogu je doživjeti ako aktivnost ima određene karakteristike (jasan cilj, jednostavna, zanimljiva), ako vide vezu između te aktivnosti i ostvarenja svojih budućih životnih ciljeva i ako aktivnost pridonosi izgradnji njihova socijalnog identiteta. Pritom pasivne aktivnosti, poput predavanja, imaju najmanje potencijala za izazivanje zanesenosti.

Kako je navedeno ranije, zanesenost je ugodno iskustvo, a ujedno i iskustvo u kojem je potpuni kapacitet svijesti usmjeren na aktivnost te osoba u takvu stanju nema vremena za neugodne i anksiozne misli, zbog čega bi zanesenost mogla djelovati kao zaštitni čimbenik. Dosadašnja su istraživanja pokazala da zaista postoji negativna povezanost između akademske zanesenosti i sagorijevanja (Ljubin Golub i sur., 2014; Rijavec i sur., 2017). Međutim, navedena su istraživanja transverzalnog tipa te imaju ograničenja u pogledu zaključivanja o uzročno-posljedičnim odnosima. Također, neka su istraživanja u radnom okruženju (Fagerlind, Gustavsson, Johansson i Ekberg, 2013) pokazala da se stanje zanesenosti javlja samo u uvjetima niske razine stresa, pa je upitno koliko zanesenost može utjecati na smanjenje stresa. Buduća bi longitudinalna istraživanja o povezanosti stresa i sagorijevanja sa zanesenosti kod studenata mogla dati jasnije odgovore na ta pitanja. Ako buduća istraživanja pokažu da zanesenost nije zaštitini faktor kad je u pitanju stres, to bi značilo da se mora pokušati utjecati na smanjenje studentskog stresa s ciljem veće mogućnosti za doživljavanje akademske zanesenosti.

\section{Pravci daljnih istraživanja veze akademske zanesenosti i dobrobiti studenata}

Može se zaključiti da istraživanje akademske zanesenosti u studiranju, iako tek na početku, pruža uvid o važnosti te vrste zanesenosti za dobrobit studenata. Imajući u vidu pozitivne posljedice dobrobiti u različitim područjima života, istraživanja bi uvjeta za pojavu akademske zanesenosti - kako situacijskih, tako i na individualnoj razini - mogla dati značajan i teorijski i praktični prinos u ovom području psihologije. Rezultati prikazanih istraživanja upućuju na tri moguća pravca daljnih istraživanja veze između akademske zanesenosti i dobrobiti, a to su uloga ciljeva, socijalnog identiteta i stresa.

Kako dosadašnja istraživanja upućuju na to da je veza između zanesenosti i dobrobiti jača u akademskom području jer ga studenti smatraju najvažnijim za njihove buduće ciljeve, jedan bi od pravaca istraživanja mogla biti povezanost između vrste životnih ciljeva i akademske zanesenosti te njihova uloga u dobrobiti studenata. $\mathrm{Na}$ ovakav pravac upućuje $\mathrm{i}$ jedno istraživanje provedeno na 
osnovnoškolskim učiteljima, u kojem se zanesenost na poslu pokazala kao jedan od medijatora između intrinzičnih životnih ciljeva i dobrobiti učitelja (Olčar i sur., 2017).

Također bi bilo važno istražiti vezu između socijalnog identiteta studenata i dobrobiti, kao i moguću ulogu akademske zanesenosti u tom odnosu. Neka istraživanja upućuju na to da ljudi češće doživljavaju zanesenost u aktivnostima koje su važne za njihov socijalni identitet (Mao, Roberts, Pagliaro, Csikszentmihalyi i Bonaiuto, 2016). Kako istraživanja pokazuju povezanost između socijalnog identiteta i nekih aspekata dobrobiti, moguće je da je upravo zanesenost medijator u toj vezi (Sharma i Sharma, 2010). Tako je istraživanje u kojem se ispitivala veza između socijalnog identiteta, strasti za obavljanem neke aktivnosti (koncept sličan zanesenosti) i sreće pokazalo da studenti koji se više identificiraju sa svojim fakultetom s više strasti obavljaju svoje akademske aktivnosti, što je onda rezultiralo višom razinom pozitivnih emocija (Bernabe, Lisbona, Palaci i Martin Aragon, 2014). Buduća bi istraživanja trebala provjeriti vezu između socijalnog identiteta, akademske zanesenosti i dobrobiti studenata.

I na kraju, kao što je već navedeno, buduća bi istraživanja treba rasvijetliti do sada neistražen i složen odnos između zanesenosti, stresa i sagorijevanja kod studenata.

\section{Zaključak}

Dosadašnja su istraživanja potvrdila da se zanesenost može javiti i u obveznim akademskim aktivnostima zbog uključenosti i koncentracije koju one zahtijevaju, te da je zanesenost $u$ akademskim aktivnostima značajnija za dobrobit studenata od zanesenosti u aktivnostima u slobodnom vremenu. Pokazalo se da je doživljavanje akademske zanesenosti povezano i s karakteristikama studenata, ali i karakteristikama učenja, odnosno akademskih zadataka, kao i karakteristikama nastavnika. Istraživanja upućuju i na moguće uzroke takve povezanosti, ali i na moguće pravce budućih istraživanja u ovom području.

\section{Literatura}

Asakawa, K. (2010). Flow experience, culture, and well-being: How do autotelic Japanese college students feel, behave, and think in their daily lives? Journal of Happiness Studies, 11, 205-223. doi:10.1023/B:JOHS.0000035915.97836.89

Admiraal, W., Huizenga, J., Akkerman, S. i Dam, G. T. (2011). The concept of flow in collaborative game-based learning. Computers in Human Behavior, 27(3), 1185-1194.

Bakker, A. B. (2005). Flow among music teachers and their students: The crossover of peak experiences. Journal of Vocational Behavior, 66, 26-44. 
Bakker, A. B., Ljubin Golub, T. i Rijavec, M. (2017). Validation of the study-related flow scale based on WOLF. Croatian Journal of Education, 19(1), 147-173. doi:10.15516/ cje.v19i1.2194

Bakker, A. B., Oerlemans, W., Demerouti, E., Bruins Slot, B. i Karamat Ali, D. (2011). Flow and performance: A study among talented Dutch soccer players. Psychology of Sport and Exercise, 12, 442-450.

Bassi, M. i Delle Fave, A. (2004). Adolescence and the changing context of optimal experience in time: Italy 1986-2000. Journal of Happiness Studies, 5, 155-179. doi:10.1023/ B:JOHS.0000035914.66037.b5

Bassi, M. i Delle Fave, A. (2012). Optimal experience and self-determination at school: Joining perspectives. Motivation and Emotion, 36, 425-438. doi:10.1007/s11031-0119268-Z

Bassi, M., Steca, P., Monzani, D., Greco, A. i Delle Fave, A. (2014). Personality and optimal experience in adolescence: Implications for well-being and development. Journal of Happiness Studies, 15, 829-843. doi:10.1007/s10902-013-9451-X

Bernabe, M., Lisbona, A., Palaci, F. J. i Martin-Aragon, M. (2014). Social identity, passion and well-being in university students, the mediating effect of passion. Spanish Journal of Psychology, 17, 1-8. doi:10.1017/sjp.2014.85

Butkovic, A., Ullén, F. i Mosing, M. A. (2015). Personality related traits as predictors of music practice: Underlying environmental and genetic influences. Personality and Individual Differences, 74, 133-138. doi:10.1016/j.paid.2014.10.006

Carli, M., Delle Fave, A. i Massimini, F. (1988). The quality of experience in the flow channels: Comparison of Italian and U.S. students. U: M. Csikszentmihalyi i I. S. Csikszentmihalyi (Ur.), Optimal experience: Psychological studies of flow in consciousness (str. 288-306). Cambridge, UK: Cambridge University Press.

Chang, C-C., Liang, C., Chou, P-N. i Lin, G-Y. (2017). Is game-based learning better in flow experience and various types of cognitive load than non-game-based learning? Perspective from multimedia and media richness. Computers in Human Behavior, 71, 218-227.

Chekola, M. (2007). Happiness, rationality, autonomy and the good life. Journal of Happiness Studies, 8, 51-78. doi:10.1007/s10902-006-9004-7

Choe, K., Kang, Y., Seo, B. S. i Yang, B. (2015). Experience of learning flow among Korean adolescents. Learning and Individual Differences, 39, 180-185.

Choi, B. i Baek, Y. (2011). Exploring factors of media characteristic influencing flow in learning through virtual worlds. Computers \& Education, 57(4), 2382-2394.

Choi, D. H., Kim, J. i Kim, S. H. (2007). ERP training with a web-based electronic learning system: The flow theory perspective. International Journal of Human-Computer Studies, 65(3), 223-243. doi:10.1016/j.ijhcs.2006.10.002 
Clarke, S. G. i Haworth, J. T. (1994). 'Flow' experience in the daily lives of sixth form college students. British Journal of Psychology, 85, 511-523. doi:10.1111/j.2044-8295.1994. tb02538.x

Conner, J., Pope, D. i Galloway, M. (2009). Success with less stress. Educational Leadership, 67, 54-58.

Csikszentmihalyi, M. (1975/2000). Beyond boredom and anxiety: Experiencing flow in work and play. San Francisco, CA: Jossey-Bass.

Csikszentmihalyi, M. (1997). Finding flow. The psychology of engagement with everyday life. New York, NY: Basic Books.

Csikszentmihalyi, M. i Csikszentmihalyi, I. S. (1988). Optimal experience. Cambridge, UK: Cambridge University Press.

Csikszentmihalyi, M., Larson, R. i Prescott, S. (1977). The ecology of adolescent activity and experience. Journal of Youth and Adolescence, 6, 281-294. doi:10.1007/ BF02138940

Csikszentmihalyi, M. i LeFevre, J. (1989). Optimal experience in work and leisure. Journal of Personality and Social Psychology, 56, 815-822. doi:10.1037/0022-3514.56.5.815

Csikszentmihalyi, M. i Rathunde, K. (1992). The measurement of flow in everyday life. U: J. E. Jacobs (Ur.), Nebraska Symposium on Motivation, 1992: Developmental perspectives on motivation. Current theory and research in motivation (Vol. 40, str. 58-97). Lincoln, NE: University of Nebraska Press.

Csikszentmihalyi, M., Rathunde, K. i Whalen, S. (1993). Talented teenagers: The roots of success and failure. New York, NY: Cambridge University Press.

Culbertson, S. S., Fullagar, C. J., Simmons, M. J. i Zhu, M. (2015). Contagious flow: Antecedents and consequences of optimal experience in the classroom. Journal of Management Education, 39(3), 319-349. doi:10.1177/1052562914545336

Deci, E. L. i Ryan, R. M. (1985). Intrinsic motivation and self-determination in human behavior. New York: Plenum Press. doi:10.1177/0146167205282148

Delle Fave, A. (1996). Esperienza ottimale e fluttuazioni dello stato di coscienza: Risultati sperimentali [Optimal experience and fluctuation in the state of consciousness]. U: F. Massimini, P. Inghilleri i A. Delle Fave (Ur.), La Selezione Psicologica Umana-Teoria e Metodo D'analisi (str. 541-568). Milano, Italy: Cooperativa libraria I.U.L.M

Delle Fave, A. (2009). Optimal experience and meaning: Which relationship? Psychological Topics, 18, 285-302.

Delle Fave, A. i Bassi, M. (2000). The quality of experience in dolescents' daily life: Developmental perspectives. Genetic, Social, and General Psychology Monographs, $126,347-367$.

Delle Fave, A. i Bassi, M. (2003). Italian adolescents and leisure: The role of engagement and optimal experience. U: S. Verma i R. Larson (Ur.), Examining adolescent leisure time across cultures: Developmental opportunities and risks. New directions in child and dolescent development (str. 79-93). San Francisco, CA: Jossey-Bass. doi:10.1002/ cd.68 
Delle Fave, A. i Massimini, F. (1988). Modernization and the changing context of flow in work and leisure. U: M. Csikszentmihalyi i I. Csikszentmihalyi (Ur.), Optimal experience (str. 193-213). Cambridge, England: Cambridge University Press.

Delle Fave, A. i Massimini, F. (1992). The ESM and the measurement of clinical change: A case of anxiety disorder. U: M. W. deVries (Ur.), The experience of psychopathology: Investigating mental disorders in their natural settings (str. 280-289). Cambridge, England: Cambridge University Press.

Delle Fave, A. i Massimini, F. (2003). Optimal experience in work and leisure among teachers and physicians: Individual and bio-cultural implications. Leisure Studies, 22, 323-342.

Delle Fave, A., Massimini, F. i Bassi, M. (2011). Psychological selection and optimal experience across cultures. New York, NY: Springer.

Demerouti, E. (2006). Job characteristics, flow, and performance: The moderating role of conscientiousness. Journal of Occupational Health Psychology, 11, 266-280. doi:10.1037/1076-8998.11.3.266

Donaldson, S. I., Dollwet, M. i Rao, M. (2015). Happiness, excellence, and optimal human functioning revisited: Examining the peer-reviewed literature linked to positive psychology. Journal of Positive Psychology, 9(6), 1-11. doi:10.1080/17439760.2014. 943801

Dyrbye, L. N., Power, D. V., Stanford Massie, F., Eacker, A., Harper, W., Thomas, M. R., ... Shanafelt, T. D. (2010). Factors associated with resilience to and recovery from burnout: A prospective, multi-institutional study of US medical students. Medical Education, 44(10), 1016-1026. doi:10.1111/j.1365-2923.2010.03754.x

El Ansari, W. i Stock, C. (2010). Is the health and we llbeing of university students associated with their academic performance? Cross sectional findings from the United Kingdom. IJERPH, 7, 509-527. doi:10.3390/ijerph7020509

Engeser, S. i Rheinberg, F. (2008). Flow, performance and moderators of challenge-skill balance. Motivation and Emotion, 32(3), 158-172. doi:10.1007/s11031-008-9102-4

Engeser, S., Rheinberg, F., Vollmeyer, R. i Bischoff, J. (2005). Motivation, Flow-Erleben und Lernleistung in universitären Lernsettings [Motivation, flow experience and performance in learning settings at university]. Zeitschrift für Pädagogische Psychologie, 19, 159-172. doi:10.1024/1010-0652.19.3.159

Fagerlind, A. C., Gustavsson, M., Johansson, G. i Ekberg, K. (2013). Experience of workrelated flow: Does high decision latitude enhance benefits gained from job resources? Journal of Vocational Behavior, 83(2), 161-170. doi:10.1016/j.jvb.2013.03.010

File, J., Farnell, T., Doolan, K., Lesjak, D. i Šćukanec, N. (2013). Higher education funding and the social dimension in Croatia: Analysis and policy guidelines. Zagreb, Croatia: Institute for the Development of Education.

Freire, T., Tavares, D., Silva, E. i Teixeira, A. (2016). Flow, leisure and positive youth development. U: L. Harmat, F. Andersen, F. Ullén i J. Wright (Ur.), Flow experience: Empirical research and applications (str. 163-178). Dordrecht, Netherlands: Springer Netherlands. 
Fullagar, C. J. i Kelloway, E. (2009). 'Flow' at work: An experience sampling approach. Journal of Occupational and Organizational Psychology, 82(3), 595-615.

Gilman, R. i Huebner, S. (2003). A review of life satisfaction research with children and adolescents. School Psychology Quarterly, 18(2), 192-205. doi:10.1521/scpq.18.2.192. 21858

Greene, B. A. i Miller, R. B. (1996). Influences on achievement: Goals, perceived ability, and self regulation. Contemporary Educational Psychology, 21, 181-192. doi:10.1006/ ceps. 1996.0015

Heine, C. (1996). Flow and achievement in mathematics. (Neobjavljena doktorska disertacija). University of Chicago.

Hektner, J. M., Schmidt, J. A. i Csikszentmihalyi, M. (2007). Experience sampling method: Measuring the quality of everyday life. Thousand Oaks, CA: Sage. doi:10.4135/ 9781412984201

Ho, L.-A. i Kuo, T.-H. (2010). How can one amplify the effect of e-learning? An examination of high-tech employees' computer attitude and flow experience. Computers in Human Behavior, 26(1), 23-31. doi:10.1016/j.chb.2009.07.007

Hull, D., Williams, G. A. i Griffiths, M. D. (2013). Video game characteristics, happiness and flow as predictors of addiction among video game players: A pilot study. Journal of Behavioral Addictions, 2, 145-152. doi:10.1556/JBA.2.2013.005

Ishimura, I. i Kodama, M. (2006). Dimensions of flow experience in Japanese college students: Relation between flow experience and mental health. Journal of Health Psychology, 13, 23-34.

Kahneman, D., Diener, E. i Schwartz, N. (1999). Well-being: The foundations of hedonic psychology. New York, NY: Russell Sage.

Keller J., i Blomann, F. (2008). Locus of control and the flow experience: An experimental analysis. European Journal of Personality, 22, 589-607. doi:10.1002/per.692

Kiili, K., de Freitas, S. D., Arnab, S. i Lainema, T. (2012). The design principles for flow experience in educational games. Procedia Computer Science, 15, 78-91.

Klein, B. D., Rossin, D., Guo, Y. M. i Ro, Y. K. (2010). An examination of the effects of flow on learning in a graduate-level introductory operations management course. Journal of Education for Business, 85(5), 292-298. doi:10.1080/08832320903449600

Larson, R. W. (2000). Toward a psychology of positive youth development. American Psychologist, 55, 170-183. doi:10.1037/0003-066X.55.1.170

Lavigne, G. L., Forest, J. i Crevier-Braud, L. (2012). Passion at work and burnout: A twostudy test of the mediating role of flow ecperiences. European Journal of Work and Organizational Psychology, 21(4), 518-546. doi:10.1080/1359432X.2011.578390

Lee, E. (2005). The relationship of motivation and flow experience to academic procrastination in university students. The Journal of Genetic Psychology, 166(1), 5-14. 
Ljubin Golub, T. (2014, listopad). Povezanost korištenja kognitivnih $i$ metakognitivnih strategija sa zanesenosti u učenju [The relationship between the use of cognitive and metacognitive strategies and study-related flow]. Rad izložen na Znanstvenoj konferenciji 2. Dani obrazovnih znanosti, Zagreb. Knjiga sažetaka, str. 45.

Ljubin Golub, T., Olčar, D. i Rijavec, M. (2014, srpanj). The role of motivation and academic social context in study-related flow and burn-out. Rad izložen na 7th European Conference on Positive Psychology, Amsterdam.

Ljubin Golub, T., Rijavec, M. i Jurčec, L. (2018). Flow in the academic domain: The role of perfectionism and engagement. The Asia-Pacific Education Researcher, 27(2), 99-107. doi:10.1007/s40299-018-0369-2

Ljubin Golub, T., Rijavec, M. i Olčar, D. (2016). The relationship between executive functions and flow in learning. Studia Psychologica, 58(1), 47-58. doi:10.21909/sp.2016.01.706

Mao, Y., Roberts, S., Pagliaro, S., Csikszentmihalyi, M. i Bonaiuto, M. (2016). Optimal experience and optimal identity: A multinational study of the associations between flow and social identity. Frontiers in Psychology, 7, 67. doi:10.3389/fpsyg.2016.00067

Massimini, F. i Carli, M. (1988). The systematic assessment of flow in daily experience. U: M. Csikszentmihalyi i I. Csikszentmihalyi (Ur.), Optimal experience (str. 266-287). Cambridge, England: Cambridge University Press.

Massimini, F., Csikszentmihalyi, M. i Carli, M. (1987). The monitoring of optimal experience: A tool for psychiatric rehabilitation. Journal of Nervous and Mental Disease, 175(9), 545-549. http://dx.doi.org/10.1097/00005053-198709000-00006

Mills, M. J. i Fullagar, C. J. (2008). Motivation and flow: Toward an understanding of the dynamics of the relation in architecture students. The Journal of Psychology, 142(5), 533-553. doi:10.3200/JRLP.142.5.533-556

Moneta, G. B. (2004). The flow experience across cultures. Journal of Happiness Studies, 5, 115-121.

Moneta, G. B. (2012). On the measurement and conceptualization of flow. U: S. Engeser (Ur.), Advances in flow research (str. 23-50). New York, NY: Springer.

Moneta, G. B. i Csikszentmihalyi, M. (1996). The effect of perceived challenges and skills on the quality of subjective experience. Journal of Personality, 64, 274-310.

Mosing, M. A., Magnusson, P. K., Pedersen, N. L., Nakamura, J., Madison, G. i Ullén, F. (2012). Heritability of proneness for psychological flow experiences. Personality and Individual Differences, 53(5), 699-704. doi:10.1016/j.paid.2012.05.035

Nakamura, J. i Csikszentmihalyi, M. (2009). The concept of flow. U: C. R. Snyder i S. Lopez (Ur.), Oxford handbook of positive psychology (str. 89-105). New York, NY: Oxford University Press. 
Olčar, D. i Jurčec, L. (2017, listopad). Odnos trenutne dobrobiti i zanesenosti u različitim kontekstima: ispitivanje metodom uzorkovanja iskustva. Rad izložen na 1. međunarodnom znanstveno-stručnom skupu Odjela za psihologiju Hrvatskoga katoličkog sveučilišta, Zagreb. Knjiga sažetaka, str. 46.

Olčar, D., Rijavec, M. i Ljubin Golub, T. (2017). Primary school teachers' life satisfaction: The role of life goals, basic psychological needs and flow at work. Current Psychology, 11, 1-14. https://doi.org/10.1007/s12144-017-9611-y

Osborne, J. W. i Jones, B. D. (2011). Identification with academics and motivation to achieve in school: How the structure of the self influences academic outcomes. Educational Psychology Review, 23, 131-158. doi:10.1007/s10648-011-9151-1

Pintrich, P. R. (2004). A conceptual framework for assessing motivation and self-regulated learning in college students. Educational Psychology Review, 16, 385-407. doi:10.1007/s10648-004-0006-X

Pöhlmann, K., Jonas, I., Ruf, S. i Harzer, W. (2005). Stress, burnout and health in the clinical period of dental education. European Journal of Dental Education, 9, 78-84. doi:10.1111/j.1600-0579.2004.00359.x

Rijavec, M. i Belina, L. (2017, listopad). Zanesenost u učenju na studiju: Kvalitativna analiza. Rad izložen na 1. međunarodnom znanstveno-stručnom skupu Odjela za psihologiju Hrvatskoga katoličkog sveučilišta, Zagreb. Knjiga sažetaka, str. 47.

Rijavec, M., Ljubin Golub, T., Jurčec, L. i Olčar, D. (2017). Working part-time during studies: The role of flow in students' well-being and academic achievement. Croatian Journal of Education, 19 (Spec. Ed. 3), 157-175. https://doi.org/10.15516/cje. v19i0.2724

Rijavec, M., Ljubin Golub, T. i Olčar, D. (2016). Can learning for exams make students happy? Faculty-related and faculty-unrelated flow experiences and well-being. Croatian Journal of Education, 18(1), 153-164. doi:10.15516/cje.v18i0.2223

Rijavec, M. i Miljković, D. (2006). Pozitivna psihologija: Psihologija čije je vrijeme (ponovno) došlo. Društvena istraživanja, 15(4-5), 621-641.

Rijavec, M. i Miljković, D. (2015). Reasons for missing classes in college: The role of personality traits. Procedia-Social and Behavioral Sciences, 205, 480-484. doi:10.1016/j. sbspro.2015.09.046

Rossin, D., Ro, Y. K., Klein, B. D. i Guo, Y. M. (2009). The effects of flow on learning outcomes in an online information management course. Journal of Information Systems Education, 20(1), 87-98.

Salanova, M., Bakker, A. B. i Llorens, S. (2006) Flow at work: Evidence for an upward spiral of personal and organizational resources. Journal of Happiness Studies, 7, 1-22. doi:10. 1007/s10902-005-8854-8

Schiefele, U. i Csikszentmihalyi, M. (1995). Motivation and ability as factors in mathematics experience and achievement. Journal for Research in Mathematics Education, 26(2), 163-181. 
Seligman, M. E. P. i Csikszentmihalyi, M. (2000). Positive psychology: An introduction. American Psychologist, 55, 5-14.

Sharma, S. i Sharma, M. (2010). Self, social identity and psychological well-being. Psychological Studies, 55(2), 118-136. doi:10.1007/s12646-010-0011-8

Shernoff, D. J. i Csikszentmihaly, M. (2009). Flow in schools: Cultivating engaged learners and optimal learning environments. U: R. C. Gilman, E. S. Heubner i M. J. Furlong (Ur.), Handbook of positive psychology in schools (str. 131-145). New York: Routledge.

Shernoff, D. J., Csikszentmihalyi, M., Schneider, B. i Shernoff, E. S. (2003). Student engagement in high school classrooms from the perspective of flow theory. School Psychology Quarterly, 18(2), 158-176. doi:10.1521/scpq.18.2.158.21860

Steel, J. P. i Fullagar, C. (2009). Facilitators and outcomes of student engagement in a college setting. The Journal of Psychology, 143(1), 5-27. doi: 10.3200/JRLP.143.1.5-27

Swann, C., Keegan, R., Piggott, D. i Crust, L. (2012). A systematic review of the experience, occurrence, and controllability of flow in elite sport. Psychology of Sport and Exercise, 13(6), 807-819. doi:10.1016/j.psychsport.2012.05.006

Ullén, F., Harmat, L., Theorell, T. i Madison, G. (2016). Flow and individual differences: A phenotypic analysis of data from more than 10000 twin individuals. U: L. Harmat, F. Ørsted Andersen, F. Ullen, J. Wright i G. Sadlo (Ur.), Flow experience. Empirical research and applications (str. 267-288). Cham, Switzerland: Springer International Publishing.

Ullén, F., de Manzano, O., Almeida, R., Magnusson, P. K. E., Pedersen, N. L., Nakamura, J., Csikszentmihalyi, M. i Madison, G. (2012). Proneness for psychological flow in everyday life: Associations with personality and intelligence. Personality and Individual Differences, 52, 167-172. doi:10.1016/j.paid.2011.10.003

Waterman, A. S. (1993). Two conceptions of happiness: Contrasts of personal expressiveness (eudaimonia) and hedonic enjoyment. Journal of Personality and Social Psychology, 64, 678-691.

Wrigley, W. J. i Emmerson, S. B. (2013). The experience of the flow state in live music performance. Psychology of Music, 41, 292-305. doi:10.1177/0305735611425903

Yang, S., Lu, Y., Wang, B. i Zhao, L. (2014). The benefits and dangers of flow experience in high school students' Internet usage: The role of parental support. Computers in Human Behavior, 41, 504-513. http://dx.doi.org/10.1016/j.chb.2014.09.039

Zager Kocjan, G. i Avsec, A. (2017). Bringing the psychology of situations into flow research: Personality and situation characteristics as predictors of flow. Psihologijske teme, 26(1), $195-210$. 


\title{
Flow in Academic Activities and Students' Well-Being
}

\begin{abstract}
Flow is a highly enjoyable state people feel when they are so focused on a task that it amounts to complete absorption in an activity. The essential condition for flow state to occur is the balance between challenges and skills, with both individual's challenges and skills being above the average. Flow had been studied mostly in leisure activities, but people can also experience flow in obligatory activities, as well as in the activities with less freedom of choice, such as work or education. The positive consequences of flow include not only better achievement, but also higher levels of wellbeing. In educational context, flow was found to be related to various positive outcomes, including progress through the school curriculum, better achievement and higher well-being. In a population of college students, flow state in academic activities is less frequent than flow in other areas of students' life (such as leisure, maintenance or part-time job), but the relationship between flow in academic domain and well-being is the strongest. This paper summaries studies of academic flow in college populations, especially those dealing with possible explanations of this relationship such as the importance and usefulness of academic activities for future life goals, the development of social identity and reducing academic stress and burnout.
\end{abstract}

Keywords: academic flow, well-being, social identity, academic stress, students

\section{Flujo en las actividades académicas y el bienestar de los estudiantes}

\begin{abstract}
Resumen
El flujo es un estado psicológico muy agradable que las personas experimentan cuando están enfocadas en una actividad hasta tal punto que están completamente inmersas en ella. La condición principal para experimentar el estado de flujo es el balance entre los desafíos y las habilidades, donde tanto unos como otros tienen que estar por encima de la media para el individuo. Donde más se investigó el flujo fue en las actividades de ocio, pero la gente lo experimenta también en las actividades impuestas o las actividades en las que hay un menor grado de la libertad de elección, como trabajo o educación. El flujo tiene consecuencias positivas no sólo para la eficacia en diferentes campos de vida, sino también para el bienestar del individuo. El flujo se relaciona con diferentes resultados positivos también en el contexto académico, como p. ej. mejor dominación del currículo, mayores logros académicos, mejor bienestar de estudiantes. Cuando se trata de población estudiantil, el flujo se experimenta menos en actividades académicas que en otros campos de la vida estudiantil (tiempo libre, actividades cotidianas, trabajo casual), pero la relación entre el flujo y el bienestar está más destacada justo en el contexto académico. En este trabajo se ofrece la revisión de investigaciones del flujo académico en la población estudiantil, especialmente aquellas que indican posibles causas de dicha relación, como p. ej. la importancia y utilidad de actividades académicas para lograr futuros objetivos en la vida, la importancia de actividades académicas para construir la identidad social y la disminución del estrés y desgaste académico.
\end{abstract}

Palabras clave: flujo académico, bienestar, identidad social, estrés académico, estudiantes

Primljeno: 20.02.2018. 